\title{
THE INFLUENCE OF NUMERICAL AND STRUCTURAL CHROMOSOME MUTATIONS ON CHIASMA CONDITIONS
}

\author{
G. M. HEWITT and B. JOHN \\ A.R.C. Unit of Biometrical Genetics, Department of Genetics, The University, \\ Birmingham
}

Received 9.xi.64

\section{THE NUMERICAL MUTANTS}

FEW reports exist of polysomic animals and most of the cases that have been described come either from laboratory cultures of Drosophila or from abnormal human beings. The human studies are particularly revealing for they demonstrate most effectively that the numerical mutants which do survive are but a small fraction of those produced. Thus, while the incidence at birth of mongolism, kleinefelters syndrome, triplo-X syndrome and haplo-X syndrome are given as $\mathrm{I} / 500, \mathrm{I} / 75^{\circ}$, I/I500 and I/500o respectively (Maclean, Harnden and Court Brown, I96I), twelve chromosome mutants were found by Carr (1963) in sixty human abortuses. Of these three were XO, two were triploid, one was tetraploid and the other six were trisomics.

White (1954) has stated that the lack of trisomics in particular, and polysomics in general, among animals contrasts markedly with the situation in plants. He is of the opinion that this difference depends on the fact that genetic balance is more easily upset in complex animals than in plants which, by comparison, are relatively less differentiated. In view of the human findings, however, it would seem to us that a much more likely explanation is the lack of adequate study which has been given to this problem in natural animal populations. Indeed if the human figures are anything to go by one may need to sample several hundred individuals in order to find the one mutant. Trisomics do not arise all that frequently even in plants. In Datura, for example, they have been reported in 0.4 per cent. of the pollen grains (Burnham, I962).

What little information we do possess suggests that grasshoppers might prove suitable material for the detection of polysomic states since four cases are already on record in this group. Thus Callan (194I) found a trisomic for the third largest autosome in a sample of thirty males of Stethophyma grossa. Lewis and John (1959) observed both tri- and tetrasomic cells in an inbred stock of Pyrgomorpha dispar ( $\equiv P$. kraussi) while Sharma, Parshad and Bedi (1962) reported a similar variation in natural populations of the Indian pyrgomorphid (Chrotogonus trachypterus. More recently Hewitt (1963) has dealt with an example of a tetrasomic mosaic in Chorthippus parallelus.

Over the past two years we have been engaged in large-scale sampling of British grasshopper populations and during this study 
have encountered four individuals in which the entire germ line proved to be trisomic. Three were trisomic for the $\mathbf{M}_{6}$ chromosome while the fourth was an $M_{7}$ trisome (see John, Lewis and Henderson, 1960). One of the $M_{6}$ trisomics belonged to $C h$. parallelus but the other three trisomes all belonged to the species Myrmeleotettix maculatus. These three latter mutants also contained B-chromosomes (John and Hewitt, 1965). This we regard as more than fortuitous for, whereas the $C h$. parallelus trisomic was one of three hundred individuals examined, the three $M$. maculatus trisomes were found in a total of only sixty B-containing individuals while a further two hundred individuals lacking supernumerary chromosomes showed no evidence of numerical variation. That B-chromosomes can influence A-chromosome stability has been reported elsewhere (Ehrendorfer, 1959; Rutishauser, 1959), though in these cases the effect was on the structural rather than the numerical aspects of chromosome behaviour. In fact we find evidence for a structural influence in $M$. maculatus too. In several of the Bcontaining individuals we have studied the frequency of meiotic breakage (plate I, fig. I) rises some twenty to thirty times its normal level.

Equally significant, in our opinion, is the fact that in three of the four trisomes it was the precocious $\mathbf{M}_{6}$-chromosome which had undergone non-disjunction. That the behaviour of the centromere can be influenced by heterochromatic material is well substantiated (Novitski, 1952, I955; Lindley and Novitski, 1958) and in the case of Sciara it has been possible to demonstrate that it is the presence of heterochromatic material in the X-chromosome which determines its nondisjunction (Crouse, 196r).

Our interest in these trisomics, however, stems from the opportunity they afford for assessing the factors which regulate pairing and chiasma formation.

(a) The $\mathrm{M}_{6}$-trisomic of $\mathrm{Ch}$. parallelus (plate 1, figs. 2, 4 and 5)

This mutant was one of eleven individuals collected at Tideslow Rake in the 1963 meiotic season. Eleven of the fifty-two diplotene cells sampled had an $\mathbf{M}_{6}$-trivalent. At first metaphase this trivalent showed linear orientation in sixteen of the twenty-two first metaphase cells analysed; in the remainder it was indifferent.

The fifty-two diplotene cells were scored for chiasma frequency and the results are shown in table 1 . Since in this species it is impossible to distinguish consistently between the $\mathrm{L}_{1}$ and $\mathrm{L}_{2}$ chromosomes at diplotene, we have pooled the chiasma scores for the three L-bivalents on the one hand and the $\mathbf{N}_{\mathbf{1}_{4}}, 5,7$ and $\mathrm{S}_{8}$ bivalents on the other. Three points emerge from this data:

(i) Where a trivalent is present as opposed to a bivalent and a univalent the chiasma frequency difference can be accounted for simply in terms of the addition of the single extra chiasma required 
to produce the trivalent (mean cell chiasmata for III $v . I I+I=I 6 \cdot 73$ v. $15 \cdot 54$ ).

(ii) If $t$-tests are carried out to compare the total chiasma frequency in the three L-bivalents on the one hand and that of the $\mathbf{M}_{4},{ }_{5}, 7$ and $S_{8}$ bivalents on the other under conditions where the $M_{6}$ is present

TABLE I

A summary of the diplotene chiasma scores from the $M_{6}$ trisomic of

Ch. parallelus from Tideslow Rake

\begin{tabular}{|c|c|c|c|c|c|c|c|c|c|}
\hline \multirow{2}{*}{ Trisomic grouping } & & \multirow{2}{*}{$\begin{array}{l}\text { No. of } \\
\text { cells } \\
\text { scored }\end{array}$} & \multicolumn{3}{|c|}{ Chiasma frequency of } & \multicolumn{2}{|c|}{$\begin{array}{c}\text { Total } \\
\text { chiasmata }\end{array}$} & \multicolumn{2}{|c|}{ Mean Xta/cell } \\
\hline & & & $\mathrm{L}_{1-3}$ & $\begin{array}{c}M_{6}, 5,7 \\
+S_{8}\end{array}$ & $\mathbf{M}_{\mathbf{s}}$ & $-M_{6}$ & $+\mathbf{M}_{0}$ & $-M_{0}$ & $+\mathbf{M}_{\mathbf{s}}$ \\
\hline $\begin{array}{l}\text { Trivalent } \\
\text { Bivalent and univalent } \\
\text { Three univalents }\end{array}$ & : & $\begin{array}{r}11 \\
39 \\
2\end{array}$ & $\begin{array}{r}101 \\
367 \\
20\end{array}$ & $\begin{array}{r}61 \\
200 \\
10\end{array}$ & $\begin{array}{r}22 \\
39 \\
0\end{array}$ & $\begin{array}{r}162 \\
567 \\
30\end{array}$ & $\begin{array}{r}184 \\
606 \\
30\end{array}$ & $\begin{array}{l}14 \cdot 73 \\
14.54 \\
15 \cdot 0\end{array}$ & $\begin{array}{l}16 \cdot 73 \\
15 \cdot 54 \\
15 \cdot 0\end{array}$ \\
\hline
\end{tabular}

as a trivalent as opposed to a bivalent and a univalent, then there is no significant difference in either comparison (table 2). Clearly, the presence of the extra chiasmata has no effect on the chiasma conditions in the other members of the complement.

TABLE 2

A comparison of the chiasma frequency of the $L_{1-3}$ chromosomes on the one hand and $M_{4},{ }_{5}, 7+S_{8}$ chromosomes on the other in cells where the three $M_{6}$ chromosomes of the $\mathrm{Ch}$. parallelus trisome form a trivalent as opposed to a bivalent and univalent. Data from 50 diplotene cells

\begin{tabular}{|c|c|c|c|}
\hline Item & d.f. & $t$ & $P$ \\
\hline $\begin{array}{l}\text { Trivalent } v \text {. Bivalent }+ \text { univalent } \\
\text { (i) } L_{1-s} \text { chromosomes . } \\
\text { (ii) } \mathbf{M}_{6}, 8,+\mathrm{S}_{8} \text { chromosomes }\end{array}$ & $\begin{array}{l}4^{8} \\
4^{8}\end{array}$ & $\begin{array}{l}0.5^{1} 5^{1} \\
0.7444\end{array}$ & $\begin{array}{l}0.6 \text {, not sig. } \\
0.4-0.5 \text {, not sig. }\end{array}$ \\
\hline
\end{tabular}

(iii) By comparison with the normal individuals from the same population, the presence of the additional $\mathbf{M}_{6}$ does not appear to have raised the chiasma frequency of the trisomic individual to a level beyond that already present in the population (table 3 ).

(b) The trisomics of M. maculatus

Two of the sixteen individuals collected from Staple Hill in 1963 were $\mathbf{M}_{6}$ trisomics (plate I, fig. 3; plate II, figs. I and 5) while one out of twenty-four individuals from Kings Lynn collected in 1964 was trisomic for the $M_{7}$-chromosome (plate I, figs. 6 and 7 ; plate II, 
figs. 2, 3, 4 and 6). Table 4 summarises the pairing behaviour of the three homologues in each of these trisomes.

TABLE 3

A comparison of the mean chiasma frequency of the $M_{6}$ trisomic of $\mathrm{Ch}$. parallelus with that in the normal members of the Tideslow Rake population

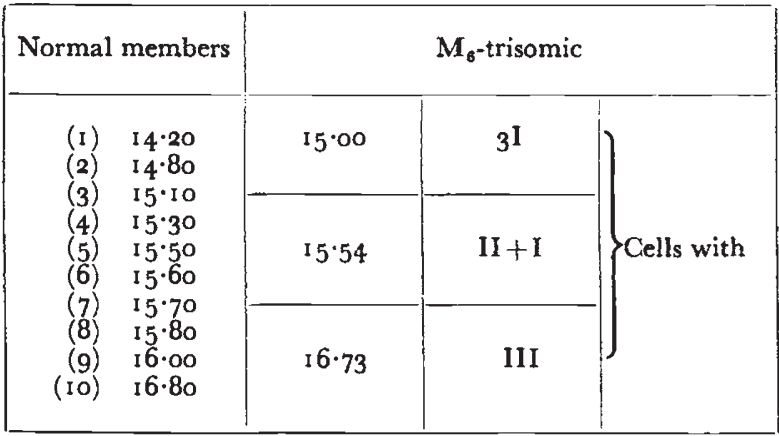

Analysis shows that in neither the $\mathbf{M}_{6}$ nor the $\mathbf{M}_{7}$ trisomics does the presence of the extra chromosomes affect the total chiasma frequency of the other bivalents in the same nucleus (tables 5-8). Clearly, chiasma formation between the three homologues is, in each case, independent of that in the remainder of the complement. When

TABLE 4

Pairing behaviour of the three M. maculatus trisomics

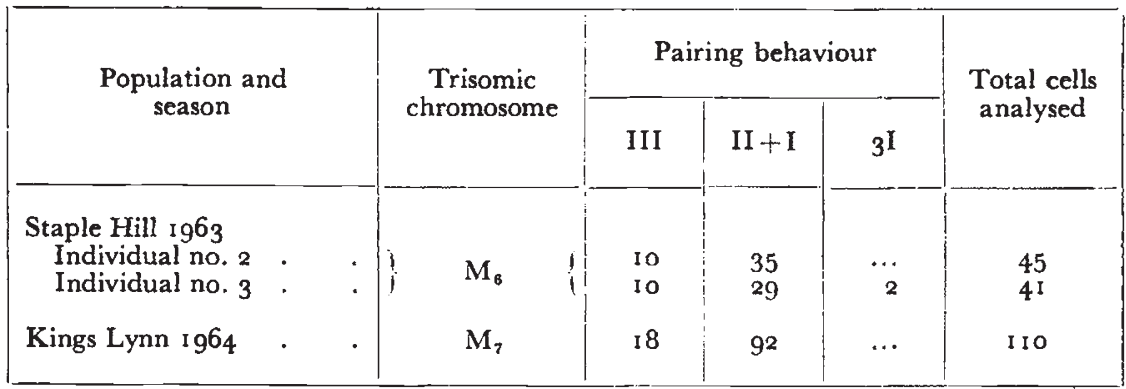

comparing the chiasma frequency of the trisomics with that of the other members of the equivalent population we need to bear in mind the fact that, as we have already shown (John and Hewitt, I965), the presence of B-chromosomes itself tends to raise the chiasma frequency in $M$. maculatus. The correct comparison is, therefore, with other B-containing members of the respective populations. And such comparisons show that the extra autosome has no influence on the chiasma frequency of the individual (table 9).

\section{THE STRUCTURAL MUTANTS}

Genetic studies in Drosophila have shown that inversions, both paraand pericentric, may, when heterozygous, increase the recombination 
frequency not only in the non-inverted regions of the inversion chromosome itself but also in other members of the complement too (see summary in Ramel, 1962). The same is true of heterozygous maize inversions (Rhoades, 1955; Bellini and Bianchi, 1963).

TABLE 5

A summary of the chiasma scores from the two $M_{6}$ trisomics of M. maculatus from Staple Hill

\begin{tabular}{|c|c|c|c|c|c|c|c|c|c|}
\hline \multirow{2}{*}{$\begin{array}{c}\text { Individual } \\
\text { No. }\end{array}$} & \multirow{2}{*}{ Trisomic grouping } & \multirow{2}{*}{$\begin{array}{l}\text { No, of } \\
\text { cells } \\
\text { scored }\end{array}$} & \multicolumn{3}{|c|}{ Chiasma frequency of } & \multicolumn{2}{|c|}{$\begin{array}{c}\text { Total } \\
\text { chiasmata }\end{array}$} & \multicolumn{2}{|c|}{ Mean Xta/cell } \\
\hline & & & $\mathrm{I}_{1-3}$ & $\begin{array}{l}\mathrm{M}_{4},{ }^{5}, \\
+\mathrm{S}_{8}\end{array}$ & $\mathrm{M}_{6}$ & $-M_{6}$ & $+M_{6}$ & $-M_{6}$ & $+\mathrm{M}_{8}$ \\
\hline S.H.2 & $\begin{array}{l}\text { Trivalent } \\
\text { Biv. .t-Univ. }\end{array}$ & $\begin{array}{l}10 \\
10\end{array}$ & $\begin{array}{l}97 \\
97\end{array}$ & $\begin{array}{l}5^{2} \\
53\end{array}$ & $\begin{array}{l}20 \\
10\end{array}$ & $\begin{array}{l}149 \\
150\end{array}$ & $\begin{array}{l}169 \\
160\end{array}$ & $\begin{array}{l}14.9 \\
15.0\end{array}$ & $\begin{array}{l}\text { I } 6 \cdot 9 \\
\text { I } 6 \cdot 0\end{array}$ \\
\hline S.H.3 & $\begin{array}{l}\text { Trivalent } \\
\text { Biv.+ Univ. }\end{array}$ & $\begin{array}{l}10 \\
10\end{array}$ & $\begin{array}{r}\text { 100 } \\
96\end{array}$ & $\begin{array}{l}4^{8} \\
49\end{array}$ & $\begin{array}{l}20 \\
10\end{array}$ & $\begin{array}{l}148 \\
145\end{array}$ & $\begin{array}{l}168 \\
155\end{array}$ & $\begin{array}{l}14.8 \\
14.5\end{array}$ & $\begin{array}{l}16 \cdot 8 \\
15.5\end{array}$ \\
\hline
\end{tabular}

White and Morley (1956) have shown cytologically that in pericentric rearrangements in Trimerotropis sparsa, $T$. gracilis and Moraba scurra the chiasma frequency of the regions distal to the rearrangements shows a pronounced increase. John and Hewitt (1963) made a

TABLE 6

A comparison of the chiasma frequency scores of the $L_{1-3}$ chromosomes on the one hand and the $M_{4},{ }_{5,7}+S_{8}$ chromosomes on the other in trisomic cells where the three $M_{6}$ chromosomes form a trivalent as opposed to a bivalent and univalent. Data from twenty cells of each of the two Staple Hill trisomics of M. maculatus

\begin{tabular}{|c|c|c|c|c|}
\hline $\begin{array}{c}\text { Individual } \\
\text { No. }\end{array}$ & Item & d.f. & $t$ & $P$ \\
\hline S.H.2 & $\begin{array}{l}\text { Trivalent } v \text {. Bivalent }+ \text { univalent } \\
\text { (i) } \mathrm{L}_{1-3} \text { chromosomes } \\
\text { (ii) } \mathrm{M}_{4},{ }_{5},+\mathrm{S}_{8} \text { chromosomes }\end{array}$ & $\begin{array}{l}18 \\
18\end{array}$ & $\begin{array}{l}0.0000 \\
0.2809\end{array}$ & $\begin{array}{l}1 \cdot 0, \text { not sig. } \\
0 \cdot 2 \cdot 0 \cdot 3, \text { not sig. }\end{array}$ \\
\hline S.H.3 & $\begin{array}{l}\text { Trivalent } \text {. Bivalent }+ \text { univalent } \\
\text { (i) } \mathrm{L}_{1_{-3}} \text { chromosomes. } \\
\text { (ii) } \mathrm{M}_{4},{ }_{5},+\mathrm{S}_{8} \text { chromosomes }\end{array}$ & $\begin{array}{l}18 \\
18\end{array}$ & $\begin{array}{l}0.5432 \\
0.2301\end{array}$ & $\begin{array}{l}0 \cdot 6, \text { not sig. } \\
0 \cdot 8, \text { not sig. }\end{array}$ \\
\hline
\end{tabular}

parallel observation in an $\mathrm{L}_{1}-\mathrm{M}_{5}$ interchange of Ch. brunneus. Here 38 per cent. of the chains of four had a chiasma in the minute arms of the acrocentric $5^{1}$ and 5 members, a position where under normal circumstances chiasmata are but rarely observed in this species.

So far as we are aware, however, no one has yet studied the question of whether interchanges, like inversions, when heterozygous influence 
TABLE 7

A summary of the diplotene chiasma scores from the $M_{7}$ trisomic of M. maculatus from Kings Lynn

\begin{tabular}{|c|c|c|c|c|c|c|c|c|}
\hline \multirow{2}{*}{ Trisomic grouping } & \multirow{2}{*}{$\begin{array}{l}\text { No. of } \\
\text { cells } \\
\text { scored }\end{array}$} & \multicolumn{3}{|c|}{ Chiasma frequency } & \multicolumn{2}{|c|}{$\begin{array}{c}\text { Total } \\
\text { chiasmata }\end{array}$} & \multicolumn{2}{|c|}{ Mean Xta/cell } \\
\hline & & $L_{1-3}$ & $\begin{array}{c}M_{4}, 5,6 \\
+S_{8}\end{array}$ & $\mathrm{M}_{7}$ & $-\mathrm{M}_{7}$ & $+\mathrm{M}_{7}$ & $-\mathrm{M}_{7}$ & $+\mathrm{M}_{7}$ \\
\hline Triv & I0 & 96 & $5^{I}$ & 20 & 142 & 167 & 14 & $16 \cdot 7$ \\
\hline Bivalent + univalent & Io & 94 & 48 & 10 & 147 & 152 & $14 \cdot 2$ & $15 \cdot 2$ \\
\hline
\end{tabular}

TABLE 8

A comparison to decide whether the chiasma frequency of the other chromosome classes is affected when the three $M_{2}$ chromosomes of the M. maculatus trisome from Kings Lynn form a trivalent rather than a bivalent and univalent. Data from 20 diplotene cells

\begin{tabular}{|c|c|c|c|}
\hline Item & d.f. & $t$ & $\mathbf{P}$ \\
\hline $\begin{array}{l}\text { Trivalent } v \text {. Bivalent }+ \text { univalent } \\
\text { (i) } \mathrm{L}_{1-3} \text { chromosomes. } \\
\text { (ii) } \mathrm{M}_{4,3,8}+\mathrm{S}_{8} \text { chromosomes }\end{array}$ & $\begin{array}{l}18 \\
18\end{array}$ & $\begin{array}{l}0.3313 \\
0.6903\end{array}$ & $\begin{array}{l}0 \cdot 7-0 \cdot 8 \text {, not sig. } \\
0 \cdot 4-0 \cdot 5 \text {, not sig. }\end{array}$ \\
\hline
\end{tabular}

TABLE 9

A comparison of the mean chiasma frequencies of the trisomic individuals of M. maculatus with that of the other members of their respective populations

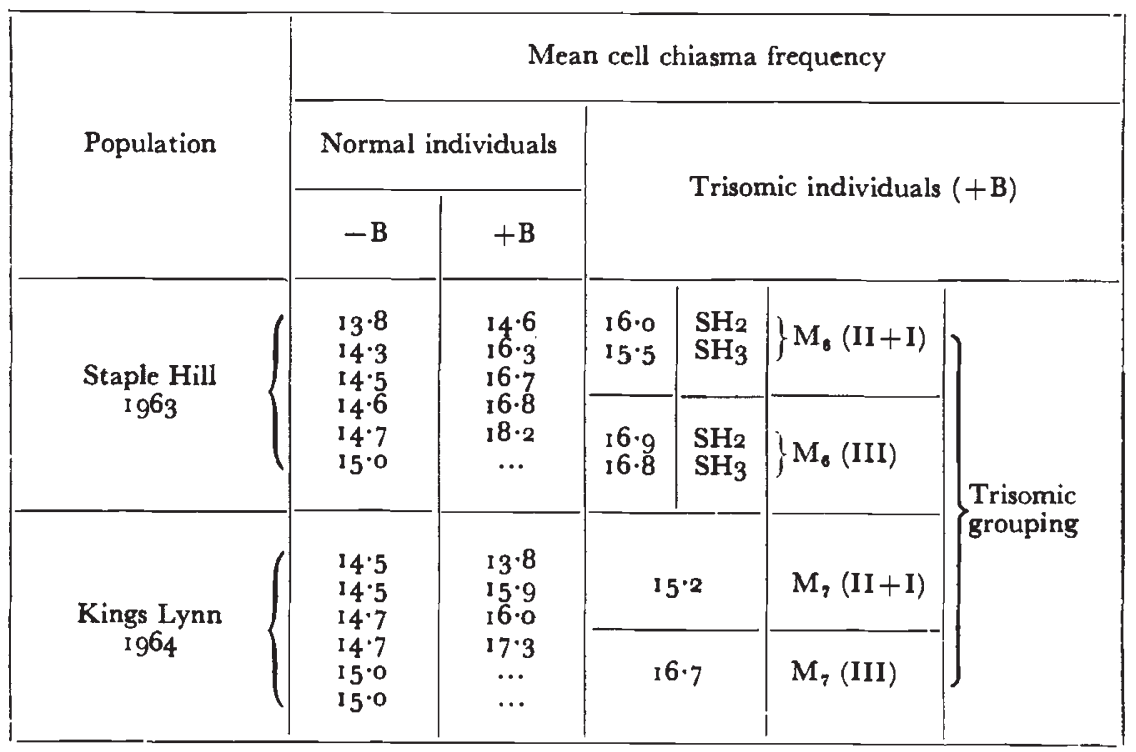


the chiasma properties of other members of the complement. We have therefore taken the opportunity to examine the situation in an $\mathrm{L}_{1}-\mathrm{L}_{3}$ interchange mosaic which we encountered in onc out of twenty individuals of Ch. brunneus collected at Silwood Park in the 1963 scason, together with that in each of the two other interchange hybrids already reported for this species (Lewis and John, I963; John and Hewitt, i 963$)$.

\section{(a) The $L_{1}-L_{3}$ interchange mosaic}

In this mutant one-quarter of the germ-line cells contained an interchange ring-multiple of four (plate II, figs. 7 and 8). Thesc multiples were in adjacent orientation in 90 per cent. of the first metaphase plates examined and altcrnate in the remainder. By using the normal cells as a control series it is possible to carry out a direct analysis of the chiasma conditions in the mutant cells which not only share the same genotype as the control sample but also the same environment. Twenty cells were scored for chiasma frequency in both the normal and the interchange types and the scores are summarised in table 10 .

TABLE 10

A summary of the chiasma counts in twenty normal and twenty $\left(L_{1}-L_{3}\right)$ interchange cells of the $\mathrm{Ch}$. brunneus interchange mosaic from Siltwood Park

\begin{tabular}{|c|c|c|c|}
\hline \multirow{3}{*}{ Bivalent class } & \multicolumn{2}{|c|}{ Chiasmata per 20 cells } & \multirow{2}{*}{ Total Xta } \\
\cline { 2 - 4 } & Normal & Interchange & \\
\hline & & & \\
\hline $\mathrm{L}_{4}+\mathrm{L}_{3}$ & 102 & 97 & 199 \\
$\mathrm{~L}_{2}$ & 52 & 5.7 & 106 \\
$\mathrm{M}_{4}$ & 25 & 28 & 53 \\
$\mathrm{M}_{5}$ & 26 & 28 & 54 \\
$\mathrm{M}_{6}$ & 21 & 20 & 41 \\
$\mathrm{M}_{7}$ & 20 & 20 & 40 \\
$\mathrm{~S}_{8}$ & 20 & 20 & 40 \\
Totals & 266 & 267 & 533 \\
\hline
\end{tabular}

The data indicate clearly that normal and intcrchange cells both form the same number of chiasmata. They also indicate that cach type of bivalent forms the same number of chiasmata under both conditions. Even the $\mathrm{L}_{1}-\mathrm{L}_{3}$ multiple forms the same number of chiasmata as its normal counterparts when these are present as separate bivalents. A heterogeneity $\chi^{2}$ confirms that all the chromosomes are bchaving similarly both under normal and under abnormal conditions (table i i).

(b) The $L_{3}-M_{4}$ and $L_{1}-M_{5}$ interchange hybrids

Ten diplotene cells from each of these heterozygotes were compared on a bivalent by bivalent basis with the equivalent of ten of the normal cells scored from the $\mathrm{L}_{1}-\mathrm{L}_{3}$ interchange mosaic (table ${ }_{12}$ ). It has 
already been shown that different populations of Ch. brunneus do not differ significantly in chiasma frequency (Hewitt, 1964). For this

TABLE II

$A$ heterogeneity $\chi^{2}$ to test the agreement between the individual bivalents with respect to chiasma formation in normal and interchange cells of the $L_{1}-L_{3}$ interchange mosaic of Ch. brunneus

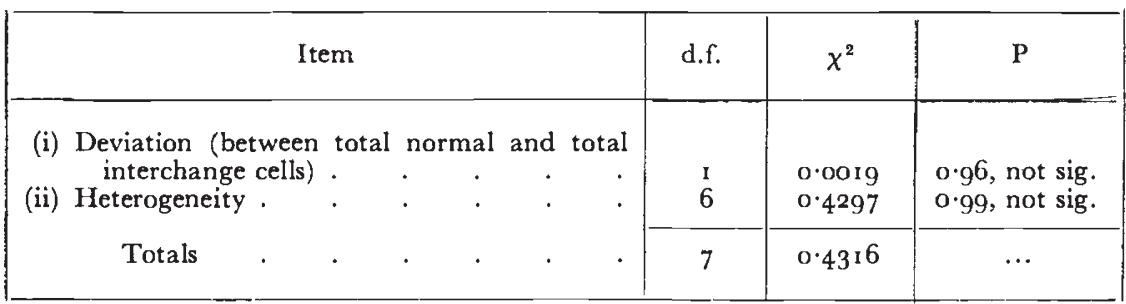

reason we have used the same normal cells to effect both comparisons since, under the circumstances, this affords the most rigorous test which it is possible to devise.

TABLE 12

A summary of the chiasma counts in the $L_{3}-M_{4}$ and $L_{1}-M_{5}$ interchange hybrids of $\mathrm{Ch}$. brunneus. The normal cells used in this comparison are from the $L_{1}-L_{3}$ interchange mosaic and represent one-half of the total of 20 cells scored

\begin{tabular}{|c|c|c|c|c|}
\hline \multirow{2}{*}{$\begin{array}{c}\text { Interchange } \\
\text { type }\end{array}$} & \multirow{2}{*}{$\begin{array}{l}\text { Bivalent } \\
\text { class }\end{array}$} & \multicolumn{2}{|c|}{ Chiasmata per ro cells } & \multirow{2}{*}{ Total Xta } \\
\hline & & Normal & Interchange & \\
\hline \multirow[t]{2}{*}{$\mathrm{L}_{3}-\mathrm{M}_{4}$} & $\begin{array}{c}\mathrm{L}_{3}+\mathrm{M}_{4} \\
\mathrm{~L}_{1} \\
\mathrm{~L}_{2} \\
\mathrm{M}_{5} \\
\mathrm{M}_{8} \\
\mathrm{M}_{7} \\
\mathrm{~S}_{8}\end{array}$ & $\begin{array}{l}34 \\
30 \\
26 \\
\text { 1 } 3 \\
\text { 10 } \\
\text { 10 } \\
\text { 1 } 0\end{array}$ & $\begin{array}{l}31 \\
31 \\
29 \\
\text { I } \\
\text { 10 } \\
\text { 10 } \\
\text { 10 }\end{array}$ & $\begin{array}{l}65 \\
6 \mathrm{I} \\
55 \\
24 \\
20 \\
20 \\
20\end{array}$ \\
\hline & Total & 133 & I 32 & 265 \\
\hline \multirow[t]{2}{*}{$\mathrm{L}_{1}-\mathrm{M}_{5}$} & $\begin{array}{c}\mathrm{L}_{1}+\mathrm{M}_{5} \\
\mathrm{~L}_{2} \\
\mathrm{~L}_{3} \\
\mathrm{M}_{4} \\
\mathrm{M}_{6} \\
\mathrm{M}_{7} \\
\mathrm{M}_{7} \\
\mathrm{~S}_{8}\end{array}$ & $\begin{array}{l}43 \\
26 \\
21 \\
13 \\
10 \\
10 \\
10 \\
10\end{array}$ & $\begin{array}{l}33 \\
30 \\
21 \\
12 \\
10 \\
10 \\
10 \\
10\end{array}$ & $\begin{array}{l}76 \\
56 \\
42 \\
25 \\
20 \\
20 \\
20 \\
20\end{array}$ \\
\hline & Total & I 33 & 126 & 259 \\
\hline
\end{tabular}

In the $\mathrm{L}_{3}-\mathrm{M}_{4}$ interchange, individual $t$-tests show that none of the classes is significantly different and a heterogeneity $\chi^{2}$ confirms that all the classes are behaving alike (table I3). In the $L_{1}-M_{5}$ 
interchange the only significant $t$-test is that involving the interchange chromosomes themselves (table ${ }_{14}$ ). This means that when the $\mathrm{L}_{1}$ and

\section{TABLE 13}

A comparison of the agreement between the individual bivalents with respect to chiasma formation in the $L_{3}-M_{4}$ and $L_{1}-M_{5}$ interchange hybrids of $\mathrm{Ch}$. brunneus. The normal cells used in this comparison come from the $L_{1}-L_{3}$ interchange mosaic of the same species

\begin{tabular}{|c|c|c|c|c|c|}
\hline $\begin{array}{c}\text { Interchange } \\
\text { type }\end{array}$ & Item & & d.f. & $x^{2}$ & $\mathrm{P}$ \\
\hline \multirow[t]{2}{*}{$\mathrm{L}_{3}-\mathrm{M}_{4}$} & \multirow{2}{*}{$\begin{array}{c}\text { (i) Deviation } \\
\text { (ii) Heterogeneity } \\
\text { Total }\end{array}$} & \multirow[t]{2}{*}{. } & $\begin{array}{l}1 \\
6\end{array}$ & $\begin{array}{l}0.003^{8} \\
0.4^{81} 4\end{array}$ & $\begin{array}{l}0 \cdot 8-0 \cdot 9, \text { not sig. } \\
0.99 \text {, not sig. }\end{array}$ \\
\hline & & & 7 & $0.485^{2}$ & $\ldots$ \\
\hline \multirow[t]{2}{*}{$\mathrm{L}_{1}-\mathrm{M}_{;}$} & $\begin{array}{l}\text { (i) Deviation } \\
\text { (ii) Heterogeneity }\end{array}$ & . & $\frac{1}{6}$ & $\begin{array}{l}0.1892 \\
0.45^{23}\end{array}$ & $\begin{array}{l}0 \cdot 6, \text { not sig. } \\
0 \cdot 95 \text {, not sig. }\end{array}$ \\
\hline & Total & . & 7 & I. 64 I 5 & $\ldots$ \\
\hline
\end{tabular}

$\mathbf{M}_{5}$ chromosomes are combined in the interchange multiple they form significantly less chiasmata than they do when independent of each other.

$$
\text { TABLE } 14
$$

A comparison between the chiasma frequencies of the $L_{1}$ and $M_{5}$ chromosonies when present as separate bivalents and when associated in an interchange multiple

\begin{tabular}{|c|c|c|c|}
\hline Item & d.f. & $t$ & $\mathrm{P}$ \\
\hline $\mathrm{L}_{1}+\mathrm{M}_{5} \ddot{2} \cdot \mathrm{L}_{1}-\mathrm{M}_{5}$ interchange & 18 & $2 \cdot 7157$ & $0.01-0 \cdot 02^{++}$ \\
\hline
\end{tabular}

\section{DISCUSSION}

The results we have presented here are consistent in demonstrating that the addition of extra homologous chromosomes of the $\mathbf{M}_{6}$ and $M_{7}$ categories have no influence on chiasma conditions in other bivalents within the same nucleus. In this they agree also with the behaviour of the $\mathrm{M}_{4}$ tetrasomic in the mosaic of Ch. parallelus described by Hewitt ( $\mathrm{r}^{6} \mathrm{6}_{3}$ ). And the implication of this finding is that in thesc four trisomics, as indeed was demonstrated in Hewitt's tetrasomic, bivalents do not compete for chiasmata in either $C h$. parallelus or $M$. maculatus. Rather, individual bivalents have considerable autonomy in respect of chiasma formation.

Like the trisomic data, that obtained from the three interchange heterozygotes also emphasises the autonomy of behaviour shown by individual members of the chromosome complement in the matter of chiasma formation. In only one case is there any significant difference in the behaviour of the chromosomes and even here it is the 
chromosomes involved in the interchange which show this difference. When associated in the $\mathrm{L}_{1}-\mathrm{M}_{5}$ multiple the $\mathrm{L}_{1}$ tends to form significantly fewer chiasmata than it does when present as a separate bivalent. The reason for this reduction is not difficult to appreciate. In this particular interchange a chiasma was formed in the interstitial segment common to the $5^{1}$ and 5 chromosomes (see fig. $8 c$, John and Hewitt, 1963 ) in $5^{8}$ per cent. of the multiples studied. And when an interstitial chiasma was present in this position a single chiasma invariably formed in the $5^{1}$ - I pairing segment adjacent to it. Since the pairing segment common to $\mathrm{I}$ and $\mathrm{I}^{5}$ never forms more than onc chiasma this ineans that only two chiasmata form in the equivalent of the $L_{1}$ pair, a pair which under normal circumstances frequently share three chiasmata.

That chiasma formation is subject to genotypic control is now beyond dispute and both major and minor genes have been implicated (Rees, 196I). Chiasma formation, however, is only one event in a sequence and it itself is preceded by processes such as pairing and coiling which are liable to influence the course of chiasma formation. Thus the long arm of chromosome $\mathrm{V}$ in Triticum astivum contains genetic elements which preclude pairing, and hence chiasma formation, between homøeologous chromosomes (Riley, rg6r). Henderson (rg63), on the other hand, found a positive correlation between the diplotene length of a particular bivalent and the number of chiasmata it contained. Processes such as these, which precede chiasma formation, are also known to come under the control of the genotype and many of them, like the amphidiploidising gene in Triticum, are likely not only to influence the behaviour of all the chromosomes in a nucleus but to influence it in the same way.

There cannot, therefore, be a single system responsible for the control of the chiasma properties of a nucleus. There must be several processes, all of which are capable of being influenced separately. Now, if the genes concerned with the production of chiasmatawhether direct or indirect in their action-operate in the conventional manner, then overall control must be chemical in character (John and Lewis, r 965). So far, however, it has been customary to interpret chiasma control in mechanical rather than in chemical terms. In such mechanistic terms two sorts of control systems have been envisaged. The onc-interference-regulates chiasma frequency and distribution within individual bivalents and this appears to be an invariable property of chiasmate systems. The only control system so far proposed to regulate chiasma frequency between bivalents in the same nucleus is competition (Mather, I936). But this is not universal. It varies even between individuals within a species (Mather, 1936; Rowlands, 1959).

Our own results can be interpreted purely in terms of interference for there are no inter-chromosomal effects in any of our mutants other than that in the $\mathrm{L}_{1}-\mathrm{M}_{5}$ interchange. This, by virtue of the fact that 
the chromosomes involved are organised into a multiple, is itself clearly the result of interference. What then of those cases where inter-chromosomal effects are beyond dispute? In several of these it has been possible to demonstrate that heterochromatic material plays a key role in the production of the effect (Suzuki, 1963; Wolf, 1963; John and Hewitt, 1965). While we do not as yet understand how the system operates, we need no longer doubt that major, let alone minor, genes can occur in heterochromatic regions (Cooper, 1959). The addition of extra heterochromatic material, or elsc its rearrangement within or between chromosomes, may well derange the several balanced systems which collectively regulate the chiasma potential of a nucleus. This is especially well demonstrated by the B-chromosome system of Myrmeleotettix maculatus. Here the addition of one or more heterochromatic B-chromosomes has a profound influence on the chiasma forming properties of all the members of the complement. In the presence of B-chromosomes there is a pronounced rise in chiasma frequency and in its variance. We are of the opinion, therefore, that inter-chromosomal effects result from an upset of one or more of the basic genotypic mechanisms responsible for chiasma control. Indeed Rowlands (1959) has already suggested how competition might be accounted for in just such terms. This implies that competition may be a manifestation of deranged control rather than a system of control in its own right.

We are not suggesting that the autonomy of bivalent behaviour which we find in grasshoppers negates the idea of a general control of chiasma conditions within the nucleus. Rather it suggests that when conditions are optimal, the control mechanisms allow each bivalent complete freedom of expression within the limits imposed by the interference relationships operating within each of them. As a result, bivalents exhibit individuality and hence apparent autonomy of response. Only when one or more of the regulatory mechanisms is disturbed will the bivalents respond in concert rather than as autonomous units.

\section{SUMMARY}

I. The chiasma conditions have been analysed in four mutant individuals, three of which had a germ line trisomic for the $\mathbf{M}_{6}$ chromosome ( $\mathrm{I}$ in $\mathrm{Ch}$. parallelus and 2 in M. maculatus) and one which was trisomic for the $\mathrm{M}_{7}$ chromsome ( $M$. maculatus). In each case the results have been compared with equivalent disomics from the relevant populations.

2. A similar study has been made in three interchange hybrids of Ch. brunneus. Two of these $\left(\mathrm{L}_{3}-\mathrm{M}_{4}\right.$ and $\left.\mathrm{L}_{1}-\mathrm{M}_{5}\right)$ characterise the entire germ line while the third was a mosaic in which one-quarter of the germ line cells carried an $\mathrm{L}_{1}-\mathrm{L}_{3}$ multiple. In all three cases the normal cells from the interchange mosaic were used as a balsis for comparison. 
3. The results point to a considerable autonomy of bivalent behaviour in the matter of chiasma formation. Thus the addition of the extra homologue in the four trisomics had no influence on the chiasma conditions in any of the other bivalents in the same nucleus. Likewise no inter-chromosomal effects were detected in the interchange heterozygotes.

4. In the $\mathrm{L}_{1}-\mathrm{M}_{5}$ interchange there was a significant drop in the number of chiasmata present in the equivalent of the $L_{1}$ pair when this pair was combined in the interchange multiple. This, it is suggested, results from the new interference relationships established in the multiple following chiasma formation in the interstitial segment common to the $5^{1}$ and 5 chromosomes.

5. It is also suggested that some, at least, of the inter-chromosomal effects which do occur, including cases where bivalents compete for chiasmata, result from a derangement of one or other of the systems of genotypic control and do not represent basic control mechanisms as has been assumed in the past.

\section{REFERENCES}

BELLINI, G., AND BIANCHI, A. 1963. Interchromosomal effects of inversions on crossover rate in maize. Zeit. $f$. Vererbungs, 94, 126-1 32.

burnham, C. R. 1962. Discussions in Cytogenetics. Minnesota, Burgess Pub. Co.

CAllan, H. G. 194I. A trisomic grasshopper. Jour. Her., 32, 296-298.

CARR, D. H. 1963. Chromosome studies in abortuses and stillborn infants. Lancet, Sep. 21, 603-6o6.

COOPER, K. w. 1959. Cytogenetic analysis of major heterochromatic elements (especially $\boldsymbol{X} h$ and $r$ ) in Drosophila melanogaster and the theory of heterochromatin. Chromosoma, 10, 535-588.

CROUSE, H. V. 1960. The controlling element in sex chromosome behaviour in Sciara. Genetics, 45, 1429-1443.

EHRendorfer, F. 1960. Akzessorische Chromosomen bei Achillea: Auswirkungen auf das Fortpflanzungs system, Zahlen-Balance und Bedeutung fur die Mikroevolution (Zur Phylogenie der Gattung Achillea VI). Zeit.f. Vererbungs, 9I, 400-422.

henderson, s. A. 1963. Chiasma distribution at diplotene in a locust. Heredity, 18 , 173-19o.

HewitT, G. M. 1963. A tetrasomic mosaic in the germ line of Chorthippus parallelus. Heredity, $18,505-512$.

HEWITT, G. M. I964. Population cytology of British grasshoppers. I. Chiasma variation in Chorthippus brunneus, Chorthippus parallelus and Omocestus viridulus. Chromosoma, 15, 212-230.

JOHN, B., AND HEWITT, G. M. 1963. A spontaneous interchange in Chorthippus brunneus with extensive chiasma formation in an interstitial segment. Chromosoma, 14, $638-650$.

John, B., AND hewitt, G. м. 1965. The B-chromosome system of Myrmeleotettix maculatus. I. The mechanics. Chromosoma (in press).

JOHN, B., AND LEwIs, K. R. 1965 . The Meiotic System. Wien, Springer-Verlag (in press).

JOHN, B., LEWIS, K. R., AND heNDERson, S. A. 1960. Chromosome abnormalities in a wild population of Chorthippus brunneus. Chromosoma, II, I-20.

LEWIS, K. R., AND JOHN, B. 1959. Breakdown and restoration of chromosome stability following inbreeding in a locust. Chromosoma, $10,5^{89}-6$ r 8 . 


\section{Plate I}

All acetic orcein preparations of diplotene cells. Figs. 4 and 5 c. $\times 3500$; all others $\mathrm{c} . \times 1400$

FIG. I. - Spontaneous chromosome breakage of the $\mathrm{L}_{\mathrm{s}}$-bivalent (arrows) in an individual of Myrmeleotettix maculatus with two B-chromosomes.

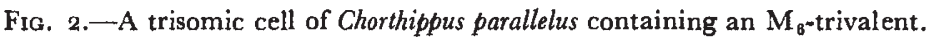

FiG. 3.-A trisomic cell of Myrmeleotettix maculatus in which the three $\mathrm{M}_{B}$ homologues are represented as a bivalent and a univalent. Note also the presence of a single B-chromosome.

FIGs. 4 and $5 .-\mathrm{M}_{6}$ trivalents from the Ch. parallelus trisome.

Fios. 6 and 7.- $\mathrm{M}_{7}$-trisomics of $M$. maculatus in which the three homologues are represented as a bivalent and univalent (fig. 6) and a trivalent (fig. 7) respectively. Note the presence of a single B-chromosome in each case. 

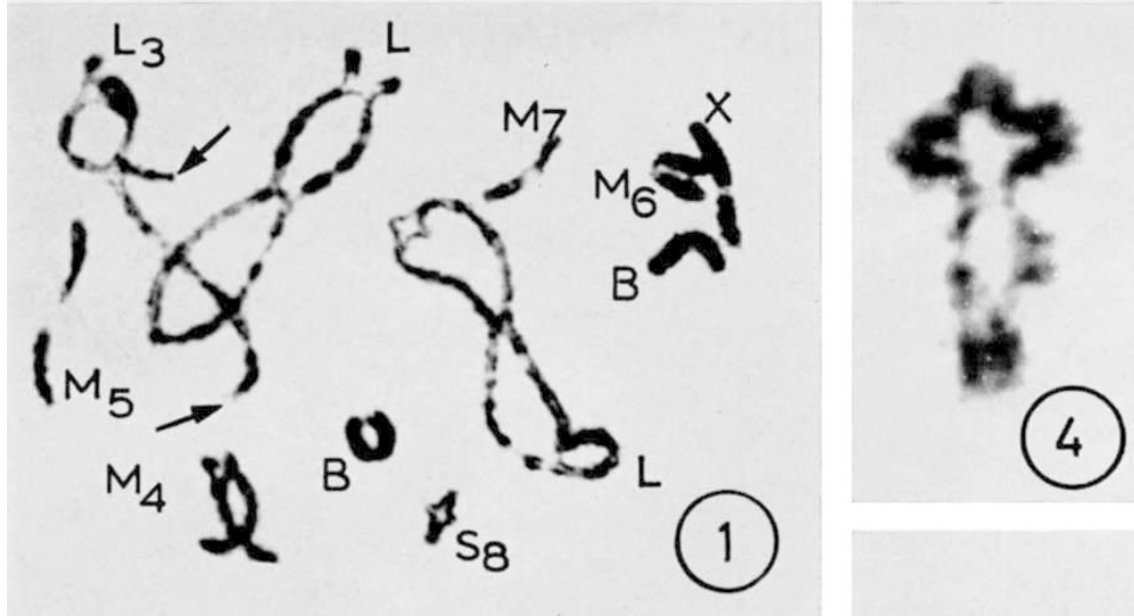

(5)

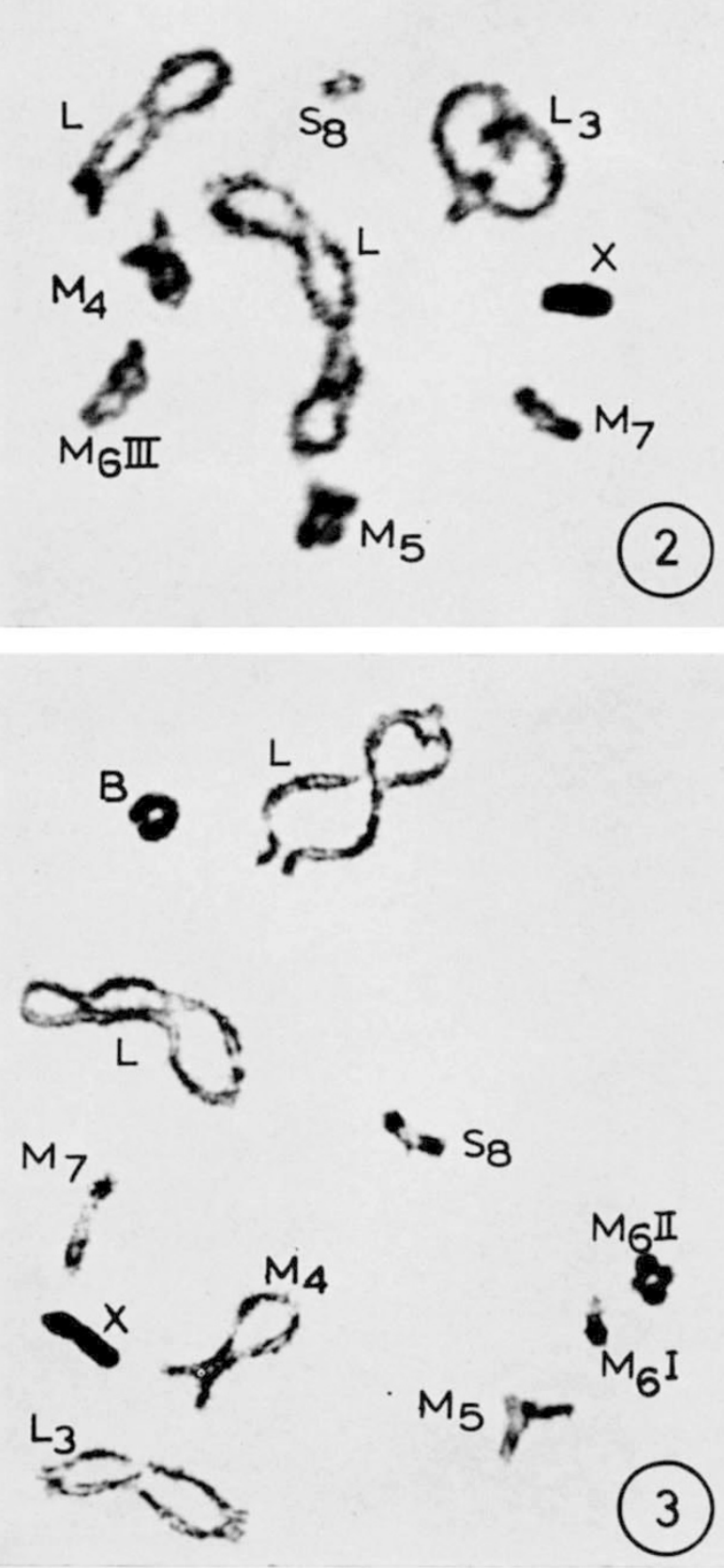

(6)

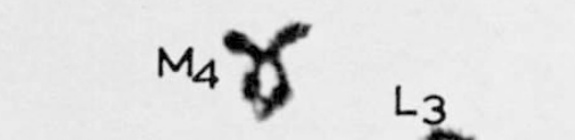




\section{Plate II}

All acetic orcein preparations of first metaphase cells, $c . \times 1400$.

FIG. 1.-Myrmeleotettix maculatus trisomic for the $\mathbf{M}_{\theta}$-chromosome. $\mathbf{M}_{\theta}$-trivalent in linear orientation. Note the presence of a single B-chromosome.

Fics. 2, 3 and 4.-B-containing cells of $M$. maculatus trisomic for the $\mathbf{M}_{7}-$ chromosome. $\mathrm{M}_{7}$-trivalent indifferent in fig. 2 and linear in fig. 3 .

Frg. 5.-M. maculatus trisomic for the $\mathbf{M}_{6}$. Note also the single B-chromosome.

FIG. 6.-A B-containing $M_{7}$-trisome of $M$. maculatus in which the three homologues form a bivalent and a univalent.

FIGs. 7 and 8.--Ring-of-four multiples in the $\mathrm{L}_{1}-\mathrm{L}_{3}$ interchange mosaic of Chorthippus brunneus. 

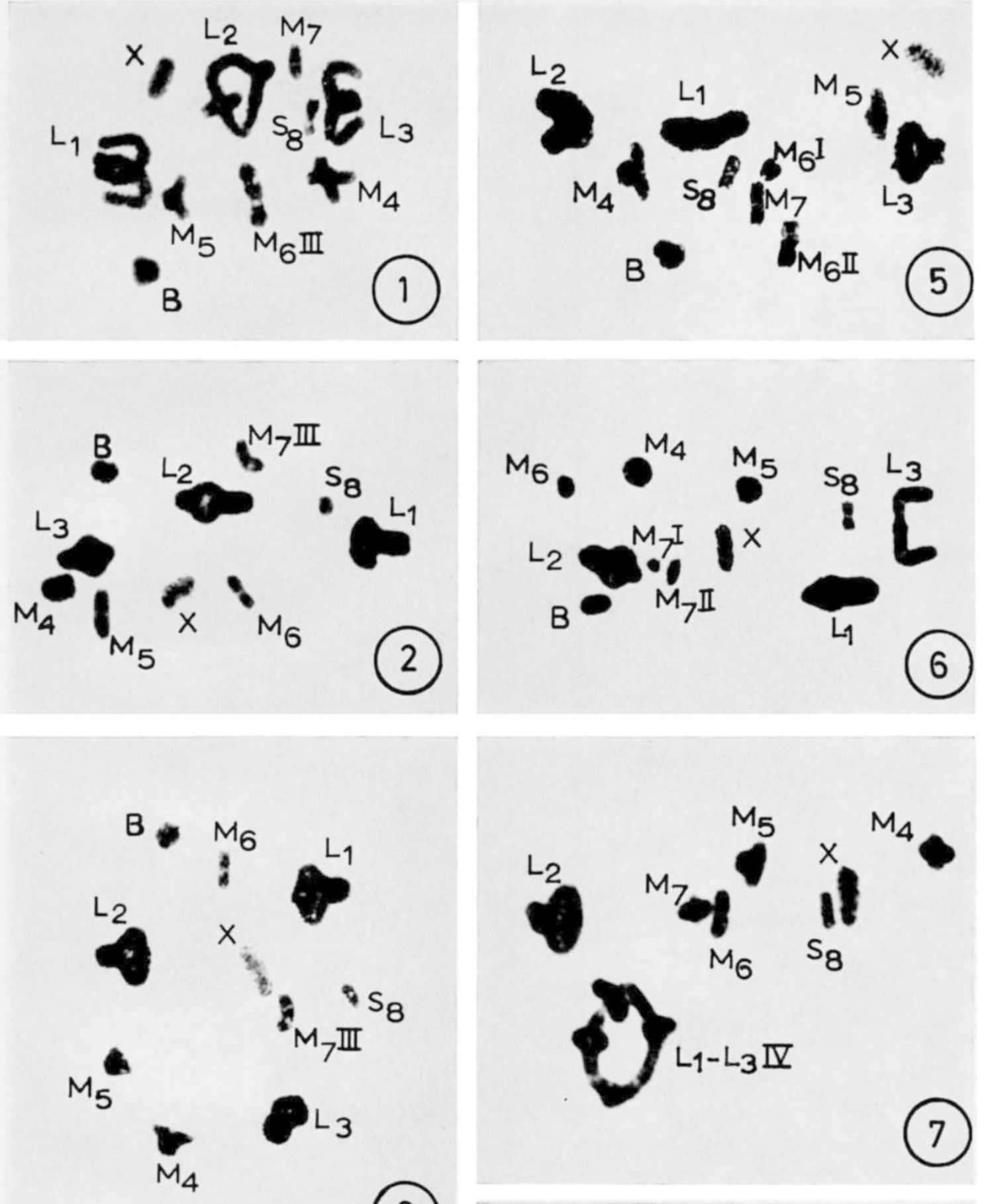

(3)
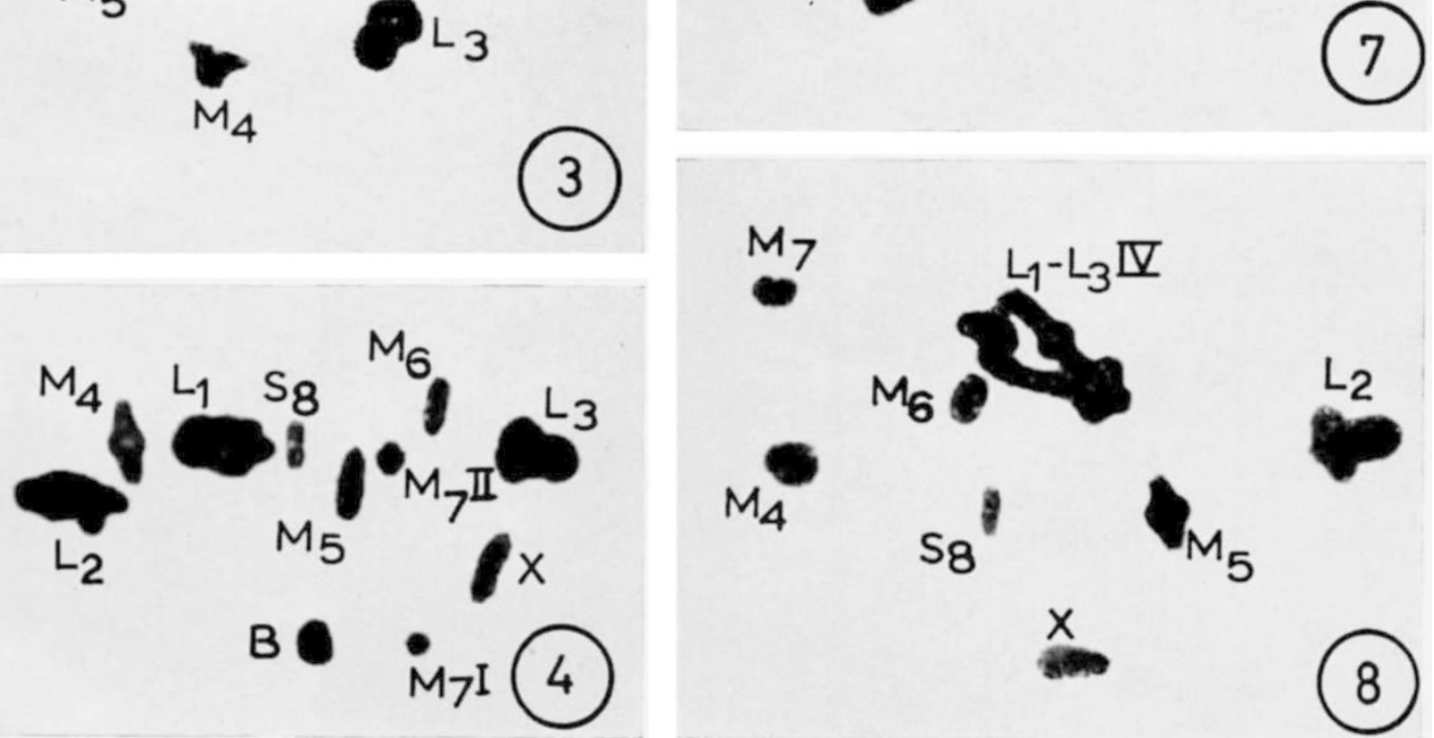
LEWTS, K. R., AND JOHN, B. 1963. Spontaneous interchange in Chorthippus brunneus. Chromosoma, 14, 6 18-637.

LINDSLEY, D. L., AND NOVITSKI, E. 1958. Localisation of the genetic factors responsible for the kinetic activity of the X-chromosomes of Drosophila melanogaster. Genetics, $43,790$.

MACLEAN, N., hARNDEN, D. G., AND courT bROWN, W. M. I96i. Abnormalities of sex chromosome constitution in newborn babies. Lancet, Aug. 19, 406-408.

mather, K. 1936. Competition between bivalents during chiasma formation. Proc. Roy. Soc. Lond., B. I 20, 208-227.

NoviTSKI, E. I952. The genetic consequences of anaphase bridge formation in Drosophila. Genetics, 37, 270-287.

NOVITSKI, E. 1955. Genic measures of centromere activity in Drosophila melanogaster. Four. Cell. Comp. Physiol., 45, Suppl. 2, $15^{1-169 .}$

RAMEL, C. 1962. Interchromosomal effects of inversions in Drosophila melanogaster. I. Crossing-over. Hereditas (Lund.), 48, I-58.

RHOADES, M. M. 1955. The cytogenetics of maize. Chapt. 4, pp. 123-220, in Corn and Corn Improvement. New York, Academic Press.

RILEY, R. 1960. The diploidisation of polyploid wheat. Heredity, 15, 407-429.

RoWlands, D. G. 1958. The control of chiasma frequency in Vicia faba L. Chromosoma, $9,176-184$.

RUtishauser, A. 196o. Zur Genetik überzhäliger Chromosomen. Archiv. der Julius Klaus-Stiftung fur Vererbungsforschung, Sozialanthropologie und Rassenhygiene, $35,440-458$.

SHARMA, G. P., PARSHAD, R., AND BEDI, S. T. 1962. Breakdown of the meiotic stability in Chrotogonus trachypterus (Blanchard) (Orthoptera: Acridoidea: Pyrgomorphidæ). Res. Bull. (N.S.) Panjab Univ., 13, 281-308.

suzuxu, D. 1963. Interchromosomal effects on crossing-over in Drosophila melanogaster. II. A re-examination of X-chromosome inversion effects. Genetics, 48 , I605-16i 7 .

white, M. J. D. 1954. Animal Cytology and Evolution. Cambridge, Univ. Press.

WHITE, M. J. D., AND MORLEY, F. H. W. 1955. Effects of pericentric rearrangements on recombination in grasshopper chromosomes. Genetics, 40, 604-619.

WOLF, B. E. 1963. Kontrolle des Crossingover vom Temperaturbedingten Allozykliegrad und vom $\alpha$-Heterochromatin des X-chromosoms bei Phryne cincta. Chromosoma, 13, 646-701. 